\title{
A SZÁRAZ SÚRLÓDÁS HATÁSAI A SZÁMÍTÓGÉPPEL MŪKÖDTETETT GÉPEK VISELKEDÉSÉRE
}

\section{DRY FRICTION EFFECTS ON COMPUTER CONTROLLED MACHINES}

\author{
Budai Csaba \\ PhD, Budapesti Müszaki és Gazdaságtudományi Egyetem Gépészmérnöki Kar \\ Mechatronika, Optika és Gépészeti Informatika Tanszék \\ budai@mogi.bme.hu
}

\begin{abstract}
ÖSSZEFOGLALÁS
Jelen tanulmány fő célja, hogy bemutassa a számítógép segítségével működtetett berendezések mozgása során fellépő olyan jelenségeket, amelyek magyarázata különböző fizikai hatások összjátékában keresendő. A tanulmány középpontjában, a pozicionálási feladatok során kialakuló különleges mozgásforma tárgyalása áll, amely egyfelől a berendezés szerkezeti felépítésében rejlő súrlódási hatások, másfelől a berendezés működtetése során felhasznált számítógépes intelligencia kölcsönhatásából eredeztethető.
\end{abstract}

\section{ABTSRACT}

The main purpose of this study is to present the phenomena occuring during the motion of computer-controlled machines where the explanation of these phenomena can be found in the interplay of different physical effects. This study focuses on the discussion of the special form of such motions that take place in positioning tasks due to the interplay between the frictional effects of the device structure and the computer intelligence used in operating the equipment.

Kulcsszavak: mozgásszabályozás, pozicionálás, száraz súrlódás, mintavételezés, stabilitás

Keywords: motion control, positioning, dry friction, sampling, stability

„Ha szeretnétek megismerni az univerzum titkait, gondoljatok az energiára, a frekvenciára és a rezgésekre!"

(Nikola Tesla)

Napjainkban egyre nagyobb teret hódítanak azon gépészeti berendezések, amelyek elektronikával és programozott intelligenciával vannak felruházva. Az intelligens gépek tudományát, amely a gépészet, az elektrotechnika és a számítógépes 
irányítás integrációját vizsgálja a termékekben, azok előállításában és tervezésében, mechatronikának nevezzük.

A következökben összefoglalt kutatás középpontjában a mechatronika egyik alapfeladata, a pozicionálási feladat állt. Pozicionálás során a vizsgált berendezésnek az a feladata, hogy egy tetszőleges kiindulási helyzetből önmüködően eljusson egy általunk megkívánt véghelyzetbe. A gépészeti gyakorlatban a feladat végrehajtásához szükség van egy szabályozó egységre, azaz egy logikára, amit követve a berendezés megvalósítja a mozgást. Ezt a logikát többnyire számítógép segítségével valósítjuk meg.

A mozgás létrehozásához a logikán felül szükség van egy olyan eszközre is, amely lefordítja a számítógépben létrehozott logika által meghatározott törvényszerüséget a fizikai valóság számára. Továbbá egy olyan eszközre is, amely a fizikai valóságot fordítja le a logika nyelvére. A müszaki életben az előbbit beavatkozó, míg az utóbbit érzékelő egységnek nevezzük.

A mindennapi életben, amikor a kezünket használjuk, és tárgyakat mozgatunk, mi is pozicionálási feladatot hajtunk végre. Esetünkben a szabályozást az agyunk végzi, illetve a feladat végrehajtásához szükséges erőt vagy nyomatékot az izmaink állítják elő, a tárgy aktuális és célhelyzete közötti távolságot pedig a szemünk méri fel.

A pozicionálási feladat kísérleti úton történő vizsgálata érdekében egy, az 1. ábrán látható mérési összeállítást hoztam létre, amelynek a központi eleme egy egyenáramú motor.

A kísérlet során attól függően, hogy mekkora feszültséget kapcsolunk a motor kivezetéseire, más és más nyomaték fog hatni a motorra szerelt korongra, végeredményében ezáltal tudjuk elfordítani a korongot a megkívánt szöghelyzetbe.

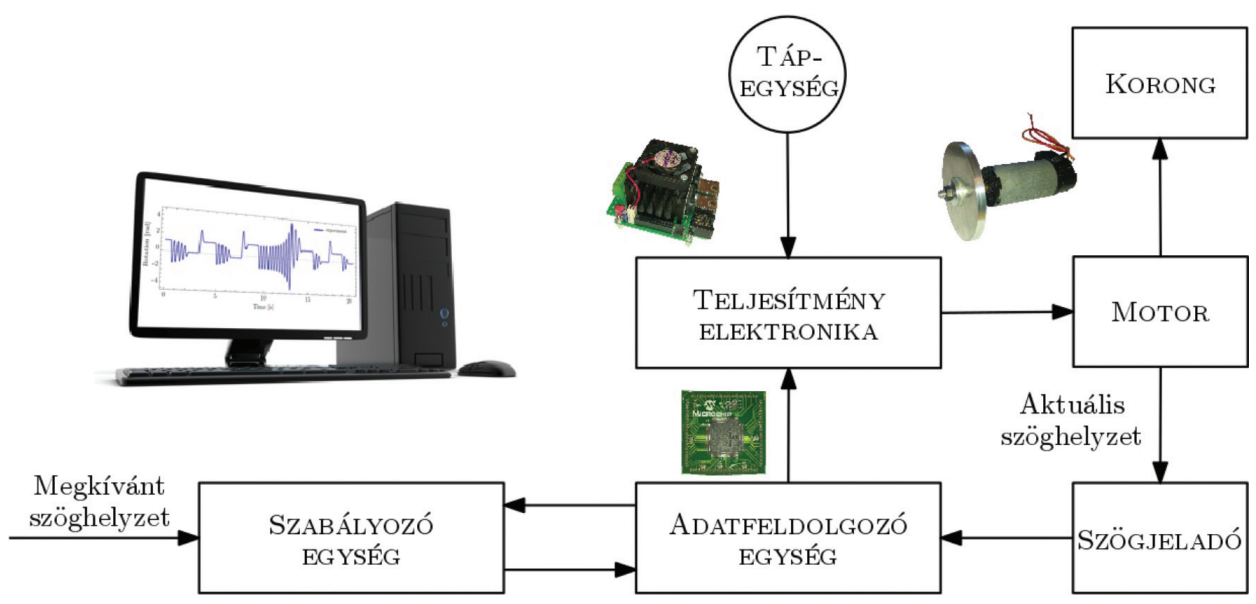

1. ábra. A mérési összeállítás központi elemének sematikus ábrája (saját szerkesztés) 
A megkívánt szöghelyzet elérésének egyik legegyszerübb módja az, hogyha az idő múlásával folyamatosan figyeljük a megkívánt és az aktuális szöghelyzet viszonyát egymáshoz, és a megfigyelt viszonyt figyelembe véve módosítjuk a motor kivezetésére kapcsolt feszültség értékét.

Abban az esetben, amikor az aktuális szögérték kisebb a megkívántnál, akkor magasabb feszültséget kapcsolunk a motorra, ezáltal nagyobb nyomatékkal hatunk a korongra, illetve ha az aktuális szögérték nagyobb, mint a célérték, akkor pedig kisebb feszültséget kapcsolunk a motorra, ezáltal kisebb nyomatékkal fogunk hatni a korongra. Így azt a logikát követjük, hogy a célérték eléréséhez az aktuális és a célérték között mérhető eltéréssel arányosan fejtünk ki nyomatékot a korongra. A müszaki gyakorlatban ezt a logikát arányos szabályozásnak nevezzük.

Az imént bemutatott kísérlet elvégzése során egy különleges rezgőmozgást tapasztaltam. Ez a mozgásforma föként azért volt meglepö, mert a pozicionálás folyamán a 2. ábra bal oldali két paneljén szereplő mozgásokat szoktuk meg. Ezektől, a mérnöki gyakorlatban megszokott mozgásoktól eltérően, a 2. ábra jobb oldali paneljén látható rezgést tapasztaltam. Ehhez hasonló rezgésforma ugyan a nemzetközi szakirodalomban is megjelenik (Diolaiti et al., 2006), ellenben a kialakulásának okát ez idáig nem tárgyalták.
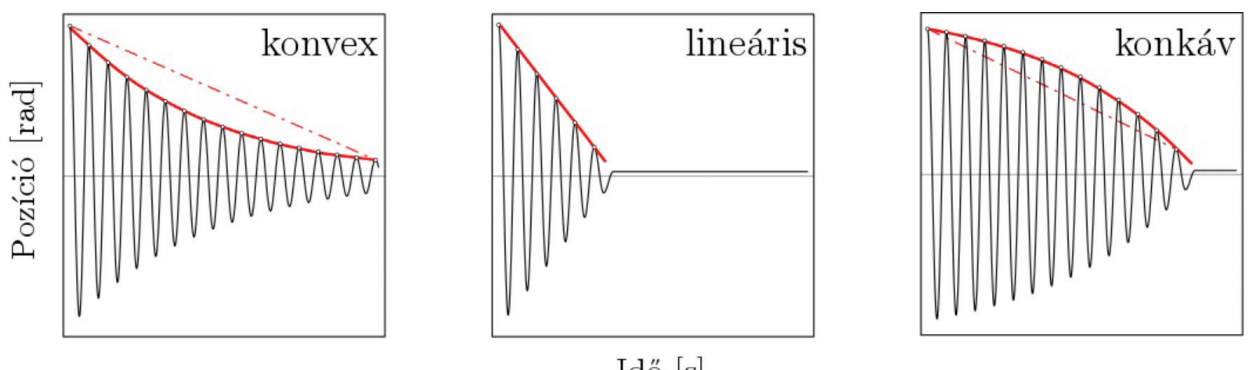

Idő $[\mathrm{s}]$

2. ábra. A különböző alakú rezgések sematikus ábrái (saját szerkesztés)

A későbbi kutatás legfőbb motivációját ennek a különleges viselkedésnek a megértése adta. Arra voltam kíváncsi, melyik az a legegyszerübb reprezentatív matematikai modell, amelynek segítségével reprodukálni tudom ezt a fajta különleges, a kísérletek során tapasztalt mozgást jellemző rezgést.

Ahogy a 2. ábrán is látható, az idő múlásával az adott időközönként mérhetö, legnagyobb szögelfordulások nagysága egy bizonyos törvényszerűségnek megfelelően folyamatosan csökken. Ennek az az oka, hogy a kezdetben létrehozott energiamennyiséget valamilyen csillapító hatás, jelen esetben a súrlódás folyamatosan csökkenti. Hasonlóan, mint amikor egy tárgyat arrébb lökünk az asztalon, a 
súrlódás folyamatosan csökkenti a kezdeti energia mennyiségét, ennek következtében a tárgy egy bizonyos idő után megáll.

A gépészeti gyakorlatban a súrlódási jelenségek vizsgálata és modellezése (Marques et al., 2016) az egyik legbonyolultabb feladat, hiszen a súrlódás jelenléte sokszor meglepő viselkedést eredményezhet. Ilyen váratlan viselkedést tapasztalunk a hétköznapjainkban, amikor megpróbáljuk lassan és halkan becsukni az ajtót. Ilyenkor a zsanérok felületén az ún. akadozó csúszás jelensége léphet fel, amit nyikorgó hanghatás kísér. Az ajtót gyorsan becsukva ezt nem tapasztaljuk.

Azonban a szóban forgó különleges rezgőmozgás megértéséhez a súrlódás hatásának figyelembevétele a jelenség teljes magyarázatának csak az egyik fele. A jelenség kialakulásának másik kiváltó oka a felhasznált logika számítógépi megvalósítása. Maga a számítógép, a digitális jellegéből kifolyólag csak meghatározott időpillanatokban képes információhoz jutni a hozzákapcsolt berendezés mozgásáról, legyen ez az idő bármennyire is kicsi (Stépán et al., 1990; Hulin-Albu-Schäffer, 2014).

Ugyan a gépészeti gyakorlatban számos feladat vizsgálata során a számítógépek effajta tulajdonsága elhanyagolható, azonban a jelen feladat vizsgálata során mégis elengedhetetlen a figyelembevétele. Ellenkező esetben a 2. ábra paneljei közül a középsőn bemutatott mozgásformát kellett volna tapasztalnom.

A különleges mozgásforma kialakulása mellett, a kísérletek elvégzése során egy másik, szintén nem várt jelenséget is tapasztaltam. Azoknál a vizsgálatoknál, amikor csak azt figyeltem, hogy amikor a célpozíciót is és a szabályozó egység általunk megválasztható paramétereit, azaz a számítógép mintavételezési idejét, illetve a szabályozó egység erősítési tényezőjét is változatlanul hagytam, akkor pusztán a kezdeti pozíció értékváltoztatására érzékennyé vált a mozgás. Ahogy egyre növeltem ezt az értéket, a korábban bemutatott különleges rezgés egyre hangsúlyosabbá vált, sőt egy határértéken túl a mozgás minősége is megváltozott

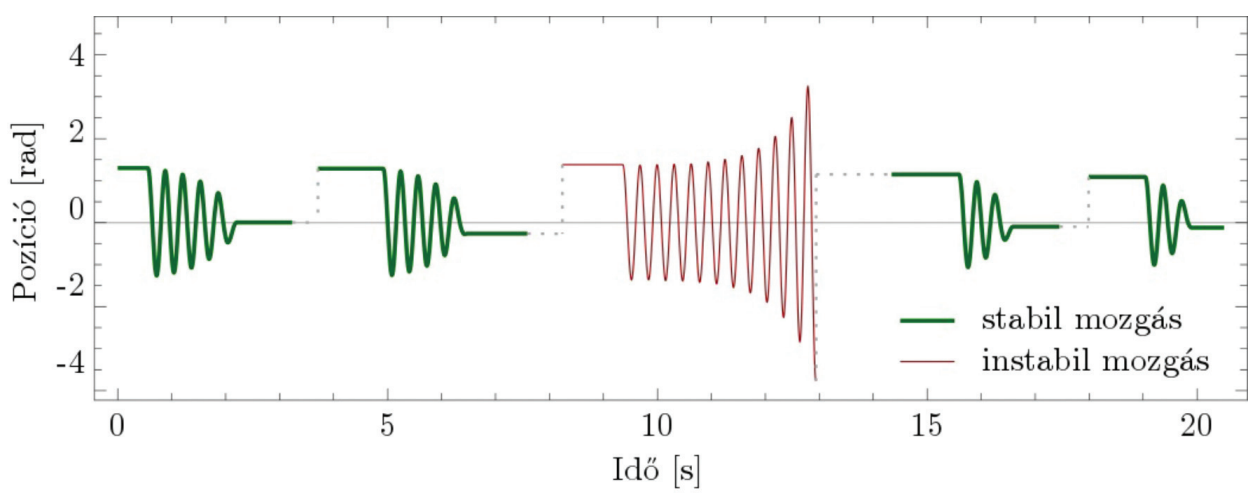

3. ábra. A kezdeti szögértéknek a mozgás minőségét befolyásoló hatása (saját szerkesztés) 
(Budai et al., 2017). Ezen érték felett a korong már nem tudta az előre meghatározott szögértéket elérni, azaz a mozgás instabillá vált. Ezt a jelenséget szemlélteti a kísérleti eredményeket összefoglaló 3. ábra.

A kutatómunka másik fő célja az volt, hogy számszerüsítsem valamilyen matematikai formula segítségével a kezdeti pozíció változtatásának imént bemutatott hatását. Ezt a 4. ábra jobb oldali paneljének szürke sávozott területe szemlélteti. Ha a kezdeti pozíció értékét csökkentem, akkor az egyre sötétebb szürke területek alakulnak ki, tehát a szabályozó egység általunk megválasztható paramétereit ebből a tartományból is megválaszthatom úgy, hogy a pozicionálási feladatot végre tudjuk hajtani (Budai-Kovács, 2017). Ebben az esetben stabil mozgás alakul ki, azonban, ha már fehér részről választjuk meg a szabályozó egység általunk megválasztható paramétereit, instabil mozgás fog kialakulni.
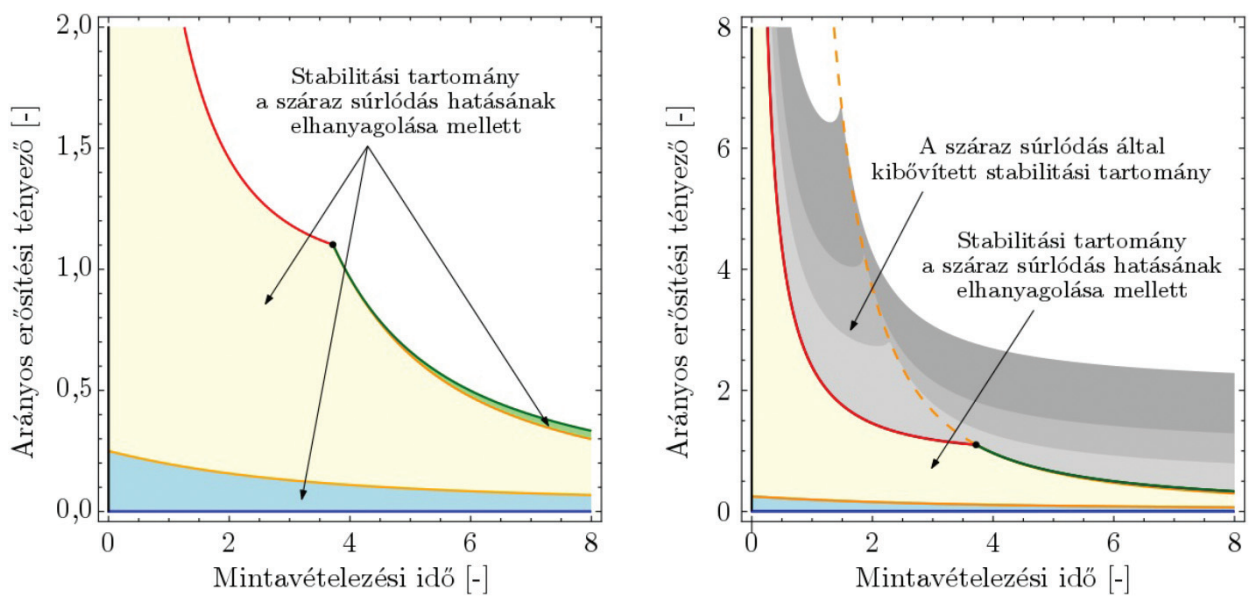

4. ábra. A kezdeti pozíció változtatásából eredő, a mozgás minőségét befolyásoló hatások szemléltetése a tervezési lehetőségek kibővítése érdekében (saját szerkesztés)

Az imént bemutatott kutatási eredményeket a kanadai McGill University Department of Mechanical Engineering and Centre for Intelligent Machines Institute-tal egy nemzetközi együttmúködés keretein belül a virtuálisvalóság-modellekben, a felhasználó számára erőérzetet biztosító feladatokban alkalmaztuk (Budai et al., 2016). Ezekben a feladatokban a szabályozott berendezés, az ún. haptikus eszköz teszi lehetővé a számítógép logikája által létrehozott virtuális erő továbbítását az ember számára.

Az ilyen feladatok különösképpen fontosak olyan robotok alkalmazásában, amelyek segítségével kisebb sebészeti beavatkozásokat végeznek. Az operáló robot, valamint a szövetek, csontok között fellépő erőhatásokat az ilyen eszközök segítségével továbbíthatjuk a beavatkozást végző sebész számára. 
Ezek az eszközök jelenleg még nem igazán terjedtek el, aminek az egyik oka abban kereshetö, hogy a számítógéppel létrehozott logika segítségével müködtetett berendezésnek, illetve magában a berendezésben fellépő súrlódási jelenségek egymásra hatását még nem ismerjük pontosan. Úgy gondoljuk, hogy az imént bemutatott eredmények fontos lépésként járulnak hozzá az új generációs eszközök tervezéséhez és fejlesztéséhez mind az orvosi, mind pedig az ipari alkalmazások körében.

\section{KÖSZÖNETNYILVÁNITT́S}

A munkám során kapott támogatásukért és hasznos tanácsaikért köszönetet szeretnék mondani Korondi Péternek, Kovács Lászlónak, Kövecses Józsefnek és Stépán Gábornak. Jelen munkát az EMMI által finanszírozott NTP-NFTÖ-17- B ösztöndíj, illetve az NKFIH által támogatott PD 128398 kutatási projekt támogatja.

\section{IRODALOM}

Budai Cs. - Kovács L. L. (2017): On the Stability of Digital Position Control with Viscous Damping and Coulomb Friction. Periodica Polytechnica Mechanical Engineering, 61, 4, 266-271 DOI: 10.3311/PPme.10537, https://pp.bme.hu/me/article/view/10537/7828

Budai Cs. - Kovács L. L. - Kövecses J. (2016): Analysis of the Effect of Coulomb Friction on Haptic Systems Dynamics. In: ASME 2016 International Design Engineering Technical Conferences \& Computers and Information in Engineering Conference (IDETC/CIE 2016), $12^{\text {th }}$ International Conference on Multibody Systems, Nonlinear Dynamics, and Control. Charlotte, North Carolina, USA, Aug. 21-24, 2016. Paper No. DETC2016-59961. DOI: 10.1115/DETC2016-59961

Budai Cs. - Kovács L. L. - Kövecses J. et al. (2017): Effect of Dry Friction on Vibrations of Sampled-Data Mechatronic Systems. Nonlinear Dynamics, 88, 1, 349-361. DOI: 10.1007/s11071016-3246-7

Diolaiti, N. - Niemeyer, G. - Barbagli, F. et al. (2006): Stability of Haptic Rendering: Discretization, Quantization, Time Delay, and Coulomb Effects. IEEE Transactions on Robotics, 22, 2, 256-268. DOI: 10.1109/TRO.2005.862487, https://www.researchgate.net/publication/3450130 Stability_of_Haptic_Rendering_Discretization_Quantization_Time_Delay_and_Coulomb_ Effects

Hulin, T. - Albu-Schäffer, A. (2014): Passivity and Stability Boundaries for Haptic Systems with Time Delay. IEEE Transactions on Control Systems Technology, 22, 4, 1297-1309. DOI: 10.1109/TCST.2013.2283372, https://www.researchgate.net/publication/263128567_Passivity_ and_Stability_Boundaries_for_Haptic_Systems_With_Time_Delay

Marques, F. - Flores, P. - Pimenta Claro, J. C. et al. (2016): A Survey and Comparison of Several Friction Force Models for Dynamic Analysis of Multibody Mechanical Systems. Nonlinear Dynamics, 86, 3, 1407-1443. DOI: 10.1007/s11071-016-2999-3

Stépán, G. - Steven, A. - Maunder, L. (1990): Design Principles of Digitally Controlled Robots. Mechanism and Machine Theory, 25, 5, 515-527. DOI: 10.1016/0094-114X(90)90066-S 